\title{
A restauração de Judá-Jerusalém: análise exegética de Jl 4,18-21
}

\author{
Orientador: Leonardo Agostini Fernandes \\ Mestrando: Davi Alves Macaneiro \\ Área de Concentração: Teologia Bíblica
}

Linha de Pesquisa: Análise e Interpretação de Textos do Antigo e Novo Testamento

O presente estudo exegético trata da restauração de Judá-Jerusalém descrita em Jl 4,18-21. A partir de uma concepção unitária dos oráculos do yôm YHWH em Joel, como um anúncio de juízo com duplo efeito, e da estrutura geral do livro como uma lamentação nacional (cf. Jl 1,1-2,18) seguida da resposta de YHWH (cf. Jl 2,19-4,21), compreendendo-se que a restauração de Judá-Jerusalém é o resultado previsto pelo juízo definitivo no yôm YHWH, consequência da presença salvífica de YHWH no Templo e Sua resposta favorável à liturgia de lamentação suplicante realizada pela comunidade dos filhos de Judá. A unidade literária J1 4,18-21 é apresentada como um oráculo salvífico e escatológico com duplo anúncio. Nela, a restauração de Judá-Jerusalém é descrita como restauração escatológica da terra eleita e do povo eleito. Através de "palavras chave", J1 4,18-21 responde aos problemas retratados no livro: uma catástrofe agrícola (cf. J1 1,2-2,27) e uma catástrofe política (cf. J1 $3,1-4,17)$. Além disso, sua estrutura formal reflete as duas etapas da resposta de YHWH a ambos os problemas: a restauração da terra (cf. J1 2,18-27) e a restauração da nação (cf. J1 3,1-4,17). Desse modo, pode-se compreender a densidade temática de J1 4,18-21 e sua função conclusiva, retomando, sintetizando e finalizando as principais linhas temáticas do livro, e levando ao ponto mais alto a argumentação desenvolvida no livro inteiro.

Palavras-chave: Exegese do Antigo Testamento. Literatura Profética. Livro de Joel. 